\title{
In-Hospital Cardiac Complications in Legionnaires' disease: A Single Center Experience of 32 Patients
}

\section{Lejyoner Hastalıg̃ında Hastane İçi Kardiyak Komplikasyonlar: Tek Merkezin 32 Hasta Deneyimi}

\author{
Sinan AKINCI', Ali CONER', Haluk ERDOG̃AN² \\ ${ }^{1}$ Department of Cardiology, Bașkent University Faculty of Medicine, Alanya Application and Research Center, Antalya, Turkey \\ 2 Department of Infectious Diseases and Clinical Microbiology, Alanya Alaattin Keykubat University Faculty of Medicine, \\ Antalya, Turkey
}

Cite this article as: Akıncı S, Çoner A, Erdoğan H. In-hospital cardiac complications in Legionnaires' disease: A single center experience of 32 patients. FLORA 2021;26(3):497-503.

\begin{abstract}
Introduction: Legionella species frequently causes Legionnaires' disease (LD), a community-acquired pneumonia (CAP). Although data on cardiac events during the course of CAP can be found in the literature, there has been little research on the same issue in LD patients specifically. This study aimed to investigate cardiac complications in the course of $L D$.

Materials and Methods: A total of 32 patients hospitalized with CAP and who received a definitive diagnosis of Legionella infection were identified from the hospital database and included in the study population. The patients' electronic and written records were evaluated for possible cardiac complications.

Results: Mean age was $65 \pm 13.5$ years and $50 \%$ of the subjects were males. Seven patients died during hospitalization. Cardiovascular events were detected in 11 patients. New-onset atrial fibrillation was the most frequent event and was detected in 8 patients (25\%), while two patients experienced a myocardial infarction, and one patient was diagnosed with myocarditis. The cardiovascular events were significantly related to the pneumonia severity index (PSI) score and need for intensive care unit.

Conclusion: Although LD rarely involves the heart, it can often cause cardiac complications, and the frequency increases in parallel with the severity of the disease. This study indicates that patients with $L D$ should be carefully followed for possible cardiac complications.

Key Words: Arrhythmias; Complications; Heart; Legionella
\end{abstract}


Öz

\title{
Lejyoner Hastalıg̃ında Hastane İçi Kardiyak Komplikasyonlar: Tek Merkezin 32 Hasta Deneyimi
}

\author{
Sinan AKINCl', Ali ÇONER', Haluk ERDOG̃AN²
}

\footnotetext{
${ }^{1}$ Bașkent Üniversitesi Tıp Fakültesi, Alanya Uygulama ve Araștırma Merkezi, Kardiyoloji Anabilim Dalı, Antalya, Türkiye

${ }^{2}$ Alanya Alaattin Keykubat Üniversitesi Tıp Fakültesi, İnfeksiyon Hastalıkları ve Klinik Mikrobiyoloji Anabilim Dalı, Antalya, Türkiye
}

Giriş: Legionella bakterileri sıklıkla, bir toplum kökenli pnömoni (TKP) olan Lejyoner hastalığına (LH) neden olur. TKP seyri sırasında kardiyak olaylarla ilgili veriler literatürde bulunabilmesine rağmen, özellikle LH hastalarında aynı konu hakkında çok az araştırma yapılmıştır. Bu çalışma, LH seyrindeki kardiyak komplikasyonları araştırmayı amaçladı.

Materyal ve Metod: TKP ile hastaneye yatırılan ve kesin Legionella infeksiyonu tanısı alan toplam 32 hasta hastane veri tabanından belirlenmiş ve çalısma popülasyonuna dahil edilmiştir. Olası kardiyak komplikasyonlar açısından hastaların elektronik ve yazılı kayıtları değerlendirildi.

Bulgular: Ortalama yaş 65 \pm 13.5 yıldı ve hastaların \%50'si erkekti. Hastane içerisinde yedi hastada mortalite izlendi. 11 hastada kardiyovasküler olay izlendi. Yeni başlayan atriyal fibrilasyon en sık görülen kardiyovasküler olaydı ve 8 hastada (\%25) tespit edildi. iki hasta miyokardiyal enfarktüs ve bir hasta miyokardit tanısı kondu. Kardiyovasküler olaylar pnömoni ciddiyet indeksi (PSI) skoru ve yoğun bakım ünitesi ihtiyacı ile anlamlı şekilde ilişkiliydi.

Sonuç: LH direkt olarak kalbi nadiren tutmaktadır. Ancak hastalığın şiddetine paralel olarak kardiyak komplikasyonlar sık olarak izlenmektedir. Bu çalışma LH'nın olası kardiyak komplikasyonlar açııından dikkatle takip edilmesi gerektiğini göstermektedir.

Anahtar Kelimeler: Aritmi; Komplikasyon; Kalp; Legionella

\section{INTRODUCTION}

Legionella species are aerobic, gram-negative bacilli and may colonize in aquatic media ${ }^{[1,2]}$. Since first detected in 1977, the genus Legionella bacteria have been known to be a common cause of community-acquired pneumonia. Generally, Legionella bacteria cause two distinctive infections: Legionnaires' disease (LD) and self-limited Pontiac fever ${ }^{[3]}$. LD mostly presents with community-acquired pneumonia (CAP) and extrapulmonary involvement is rarely seen. Cardiac, central nervous system, hepatic, bone, and joint infections have been documented ${ }^{[4]}$. Epidemiological studies have shown that $0.5-10.0 \%$ of CAP cases are related to $\mathrm{LD}^{[5,6]}$. Although $\mathrm{LD}$ commonly presents as atypical pneumonia, it is impossible to perform a differential diagnosis of LD from other causes of pneumonia through physical examination alone. A successful differential diagnosis, particularly in LD cases presenting with extrapulmonary involvement, is crucial.

Cardiac complications can be seen in patients hospitalized for CAP ${ }^{[7]}$. These complications may be related to either direct involvement of the heart with a pathogenic microorganism or may be related to endotoxin. Besides, antibiotics used in the treatment of LD such as macrolides and fluoroquinolones can cause fatal arrhythmias ${ }^{[8]}$. While there are extensive studies on cardiac complications in CAP in the literature, studies on cardiac problems in LD are limited. In this retrospective analysis of patients hospitalized for $\mathrm{LD}$, we aimed to investigate the cardiac complications and possible cardiac involvement seen in the follow-up of patients.

\section{MATERIALS and METHODS}

The study was approved by the local ethics committee. The study population was selected from the in-hospital patients diagnosed with CAP and documented LD. A total of 32 patients diagnosed with LD after hospitalization with the diagnosis of CAP between 2001-2018 were evaluated.

In a patient with an acute lower respiratory infection with focal signs of pneumonia on clinical examination and/or radiologic evidence of pneumonia, definitive diagnosis of $\mathrm{LD}$ was made through one or more of three diagnostic methods: isolation of Legionella bacteria from 
respiratory secretions; immune fluorescence assay (IFA) showing a more than four-fold increase in Legionella pneumophilia serogroup-I specific serum antibody titers; and the detection of specific Legionella antigen in urine samples (9). Legionella urinary antigen was tested using the BinaxNOW® Legionella Urinary Antigen Test (Binax, Scarborough, ME). L. pneumophila specific serum antibody titers measured by Turkish Legionella $\mathrm{Re}^{-}$ ference Laboratory or Pasteur Cerba Laboratory (France). Respiratory specimens were cultured on plates containing buffered charcoal yeast extract $\alpha$ (BCYE- $\alpha$ ) agar.

Clinical follow-up, laboratory, and electrocardiographic (ECG) data were obtained from the hospital database. Patient files were reviewed for instances of acute myocardial infarction, left ventricular dysfunction, or newly developing rhythm disorders, and causes of death were recorded. Rhythm disturbances, previously known to be in sinus rhythm and developed during follow-up, were defined as newly developing rhythm disorder. Acute myocardial infarction (MI) was defined as chest pain or ischemic ECG changes with an increase in cardiac enzymes (CK-MB or Troponins) above the upper limit determined in the laboratory. Left ventricular functions were evaluated from transthoracic echocardiography recordings. Worsening heart failure could not be evaluated due to insufficient patient records. The cardiovascular event was defined as acute MI or newly developed rhythm disturbance during follow-up. Patient pneumonia severity index (PSI) scores were calculated from the records using a previously defined method ${ }^{[10]}$.

Statistical analysis was performed using the SPSS 22.0 software program (Chicago, IL, USA). Continuous variables were expressed as mean $\pm \mathrm{s}^{-}$ tandard deviation (SD) or median and interquartile ranges (IQR), and categorical variables as percentages. Distribution for normality was tested using the Kolmogorov-Smirnov test. Continuous variables between the study groups were compared using the Mann-Whitney $\mathrm{U}$ test, and categorical variables were compared using the Chi-Square or the Fisher exact test. Statistical significance was defined as $\mathrm{p}<0.05$.

\section{RESULTS}

Thirty-two immunologically non-compromised patients hospitalized for CAP and diagnosed with LD between 2001 and 2018 were identified in the hospital database. All cases were detected sporadically, except for three clusters of 9 patients. Urinary Legionella antigen was positive in all patients, besides, there was growth in the Legionella cultures of 4 patients, and serum antibody levels were found to be high with IFA in 6 patients. Patient ages ranged from 39 to 106 years of age (mean: 65 \pm 13.5 ) and 16 patients (50\%) were males. Mean duration of hospital stay was $6.7 \pm 2.6$ days. Twenty patients $(62.5 \%)$ were treated in the intensive care unit and 8 (25\%) required mechanical ventilator support. The baseline clinical characteristics of the patients are shown in Table 1.

Table 1. Clinical and demographic characteristics of the 32 Legionnaires' disease patients

$\begin{array}{lc}\text { Age, years (mean } \pm \text { SD) } & 64.7 \pm 13.5 \\ \text { Male/Female, N (\%) } & 16(50 \%) / 16(50 \%) \\ \text { Hypertension, N (\%) } & 14(43.7 \%) \\ \text { Diabetes, N (\%) } & 12(37.5 \%) \\ \text { Coronary Artery Disease, N (\%) } & 3(9.3 \%) \\ \text { Heart Failure, N (\%) } & 3(9.3 \%) \\ \text { Chronic AF } & 6(18.8 \%) \\ \text { Chronic Obstructive Pulmonary Disease, N (\%) } & 5(15.6 \%) \\ \text { CRP (mg/l), median (25 } 5^{\text {th }}-75^{\text {th }} \text { IQR) } & 294(192-320) \\ \text { PSI score (mean } \pm S D) & 110.0 \pm 48.8\end{array}$

AF: Atrial fibrillation, CRP: C- Reaktif protein, PSI: Pneumonia severity index. 
Table 2. Comparison of characteristics between 32 Legionnaires' disease patients with and without cardiovascular events

\begin{tabular}{lccc}
\hline Patient characteristics & CV event $+(\mathrm{N}:$ 11) & CV event $-(\mathrm{N}: 21)$ & p \\
\hline Age (years) & $67.7 \pm 9.5$ & $63.1 \pm 15.1$ & 0.223 \\
Male/Female, N (\%) & $8(72.7) / 3(27.3)$ & $8(38.1) / 13(61.9)$ & 0.135 \\
Hypertension, N (\%) & $7(63.6)$ & $7(33.3)$ & 0.142 \\
Diabetes, N (\%) & $5(45.4)$ & $7(33.3)$ & 0.703 \\
Coronary Artery Disease, N (\%) & $0(0)$ & $4(19.0)$ & 0.516 \\
CRP, mg/l (mean \pm SD) & $255.4 \pm 119.5$ & $231.8 \pm 107.7$ & 0.256 \\
PSI score (mean $\pm S D)$ & $142.3 .8 \pm 42.3$ & $93.1 \pm 43.8$ & 0.006 \\
Duration of hospitalization (days) & $6.6 \pm 2.9$ & $6.8 \pm 2.5$ & 0.876 \\
Intensive care (N/\%) & $10(90.1)$ & $10(47.6)$ & 0.023 \\
Mortality (N/\%) & $4(36.3)$ & $3(14.3)$ & 0.197 \\
\hline CV: Cardiovascular, CRP: C-Reaktif protein, PSI: Pneumonia severity index. & & \\
*Statistical significance accepted as p< 0.05. & & &
\end{tabular}

Seven patients died during in-hospital followup, and the overall in-hospital mortality rate was $21.8 \%$. Six of these patients died because of septicemia and multiorgan failure, and one patient of sudden cardiac arrest (SCA). A prolonged QT interval (QTc: $650 \mathrm{msec}$ ) was detected on a 12-lead ECG recording taken on the day of the SCA. During the in-hospital follow-up period, acute atrial fibrillation (AF) developed in 8 patients (25.0\%). Two patients suffered from an acute myocardial infarction, and one patient had an attack of myopericarditis. All of the AF attacks were detected within 24 hours of the index hospitalization. The PSI scores were significantly higher in patients with acute AF (p: $0,023)$, but the mortality rate was not different (p: 0.327).

We compared the clinical and demographic characteristics of 11 patients with cardiac events and 21 patients without cardiac events. Only PSI score and need for intensive care unit (ICU) were significantly associated with cardiovascular events (Table 2). Although the mortality rate was higher in patients with cardiovascular events, it was not statistically significant.

\section{DISCUSSION}

A higher percentage of mortality in LD patients was detected in the current study than in other studies in the literature ${ }^{[5,11]}$. Our study population had an overall mortality rate of $21.8 \%$. This high mortality rate might be related to either coexisting diseases or older age. The mean age of our study population was higher on average than a previous study with a longer follow-up period $^{[5]}$. The fact that the vast majority of cases in our study were sporadic, delay in admission to the hospital, diagnosis, and treatment may have contributed to the increase in mortality ${ }^{[12]}$.

CAP is an essential public health problem. In previous studies, cardiovascular complications have been found to be common in the course of CAP. These complications have been associated with increased short-term mortality. Medina et al. have reported new or worsening heart failure, new or worsening arrhythmias, and MI in $21 \%, 10 \%$, and $3 \%$ of hospitalized patients, respectively. In the same study, overall cardiac complications have occurred in $27 \%$ of inpatients and $2 \%$ of outpatients ${ }^{[7]}$. Cardiac complications may be associated with direct damage to the heart by the pathogen, systemic inflammation, hypoxemia, or pneumonia treatment ${ }^{[8,13]}$. Possible cardiac complications seen in the course of CAP hospitalizations can be listed as MI, heart failure, myocarditis, pericarditis, and arrhythmias ${ }^{[14,15]}$.

Cardiac involvement can be seen in Legionnaires' disease. Case reports of direct cardiac involvement of $\mathrm{LD}$, such as myocarditis, pericarditis, and endocarditis, can be found in the literature ${ }^{[4,16,17]}$. Although these cases of cardiac 
involvement have been reported, there are no clear studies on cardiac complications during LD. In a retrospective study of 110 cases of LD in their clinics, Coimbra et al. have analyzed cardiac complications and found one instance of myocardial infarction (1\%), two ischemic strokes $(2 \%)$, and three patients (3\%) with de novo AF. Only the SOFA score has been found to be associated with cardiovascular events ${ }^{[18]}$. Similarly, in the current study, cardiovascular events were found to be significantly associated only with the PSI score. The frequency of cardiovascular events was found to be higher in our study than in the study conducted by Coimbra et al. This finding may be due to the fact that the cases in our study presented with a more severe clinical picture.

Cardiac arrhythmias, especially AF, are common complications of acute pneumonia ${ }^{[19]}$. Acute pneumonia can cause a wide variety of acute changes in the ECG of patients. These changes may be due to accompanying myocardial disorders, ischemia, myocardial or pericardial involvement of microorganisms, or the direct effect of pneumonia on the cardiac conduction system. Cardiac arrhythmias can also be caused by sympathetic hyperactivity or stressinduced changes in the electrical properties of cardiomyocytes and ${ }^{[13]}$. AF is the most common arrhythmia occurring in CAP patients during inhospital follow-up ${ }^{[7]}$. Studies have reported a wide range of incidents of new-onset $\mathrm{AF}$ in $\mathrm{LD}$ patients $^{[11,18]}$. We found a higher percentage of AF onsets than in previous studies, with $25 \%$ of the population experiencing a new AF attack. We documented higher CRP levels and PSI scores than these mentioned studies as well. Worse clinical presentation characterized by CRP levels and PSI scores might play a role in the higher development of new-onset AF. Also, we detected higher PSI scores in AF patients than in non-AF patients in our study population. On the other hand, we did not detect any mortality difference between $\mathrm{AF}$ and non-AF patients.

The relation between increased serum troponin concentrations and pneumonia severity without acute coronary syndrome is well defined ${ }^{[20]}$. Troponin increase may be due to MI or non- ischemic myocardial injury. Myocardial ischemia may result from increased metabolic needs in patients with preexisting coronary stenosis or may be due to acute coronary occlusion, focal spasm, severe diffuse microvascular dysfunction, or hypoxemia[13]. Despite not having investigated LD specifically, Corrales-Medina et al. have reported the frequency of $\mathrm{MI}$ in patients hospitalized with $\mathrm{CAP}$ as $3 \%^{[7]}$. In the current study, MI was found in 2 patients (6.2\%).

Myocarditis is an inflammatory disease of the myocardium in which different clinical pictures can be seen depending on the degree of involvement. It may develop due to infectious agents, drugs, or immunological reasons. LD rarely causes myocarditis ${ }^{[21]}$. In one of our cases, myocarditis due to LD was detected. Although the patient was not diagnosed with an endomyocardial biopsy, the diagnosis of myocarditis was made using clinical and echocardiographic findings. Myocarditis should be kept in mind in the differential diagnosis when unexplained acute myocardial damage is detected in a patient with LD.

Sudden death occurred in one of our patients who recovered clinically and had a prolonged QT on ECG. Even if the exact cause of death could not be determined since an autopsy was not performed on the patient, it was considered as arrhythmia resulting from prolonged QT. Combined antibiotic regimens can be dangerous for cardiac functions triggering malign arrhythmias ${ }^{[22,23]}$. Macrolides and fluoroquinolones are the most commonly used antibiotics for the treatment of LD, and both medications can have harmful arrhythmic effects on the heart. Macrolides and fluoroquinolones can also cause QT prolongation and, more rarely, polymorphic ventricular tachycardia ${ }^{[8]}$. One large retrospective study has suggested a small but statistically significant increase in the short-term risk of cardiovascular death in patients taking azithromycin compared to patients who received amoxicillin. This effect has been found higher in patients with a more prominent initial cardiovascular risk ${ }^{[23]}$. A combination of clarithromycin and rifampicin was used in our patients. Rifampin causes an increase in plasma clarithromycin level by affecting the hepatic CYP3A4 enzyme ${ }^{[24]}$. Therefore, the 
effect of clarithromycin on the QT interval may be more pronounced. Routine ECG evaluation during ongoing antibiotic treatment is essential to prevent a QT prolongation and a resultant sudden cardiac arrest. Electrolyte replacement can be helpful to restrict and minimize the devastating results of QT prolongation.

It is not clear whether all of these complications found in this study were due to the Legionella infection itself or pneumonia. The findings of our study showed that cardiac complications are frequently observed in the course of $\mathrm{LD}$. AF was the most common cardiac complication in $\mathrm{LD}$ patients. Close ECG evaluation is essential to prevent fatal arrhythmias.

\section{Limitations of the Study}

The most important limitation of the study is that it was conducted retrospectively. Due to the retrospective nature of the study, it cannot be said with certainty that in-hospital cardiac events observed in the course of LD are directly related to the disease. Also, we were unable to find electrocardiographic evaluations in some patients hospitalized with a diagnosis of $\mathrm{LD}$ and were thus unable to determine the actual prevalence of QT prolongation in the LD patients. Further prospective studies are necessary to document QT prolongation in LD. New or worsening heart failure is a common problem in pneumonia patients. Due to the retrospective nature of our study, we could not collect enough data on heart failure. A prospective registry could overcome these limitations and be useful for further research. In our study, only in-hospital cardiac events were examined. However, the effect of LD on long-term cardiac events is not clear. A long-term follow-up study will be useful to detect these events.

\section{ETHICS COMMITTEE APPROVAL}

The study was obtained from Baskent University Medical and Health Sciences Research Committee (Date: 22.01.2019, Decision No: 2773).

\section{CONFLICT of INTEREST}

The authors declare that they have no conflict of interest.

\section{AUTHORSHIP CONTRIBUTIONS}

Concept and Design: All of authors

Data Collection or Processing: SA, AC

Analysis/Interpretation: SA, AC

Literature Search: SA, HE

Writing: SA, AC

Final Approval: HE

\section{REFERENCES}

1. Burak D, Zeybek Z. Investigation of Legionella pneumophila and free living amoebas in the domestic hot water systems in Istanbul. Turk J Biol 2011;35:679-85.

2. Erdogan H, Arslan H. Colonization of Legionella species in Turkish baths in hotels in Alanya, Turkey. Environ Monit Assess 2015;187(5):235.

3. Isenman HL, Chambers ST, Pithie AD, MacDonald SLS, Hegarty JM, Fenwick JL et al. Legionnaires' disease caused by Legionella longbeachae: Clinical features and outcomes of 107 cases from an endemic area. Respirology 2016;21:1292-9.

4. Brusch JL, Legionnaire's Disease: Cardiac Manifestations. Infect Dis Clin North Am 2017;31(1):69-80.

5. Viasus D, Di Yacovo S, Vidal CG, Verdaguer $R$, Manresa $F$, Dorca J et al. Community-acquired Legionella pneumophila pneumonia: A single-center experience with 214 hospitalized sporadic cases over 15 years. Medicine (Baltimore) 2013;92:51-60

6. Zer Y, Bayram N, Balci i, Filiz A. Investigation of the causative agents for community-acquired pneumonia in adult patients. Turk J Med Sci 2010;40:47-52.

7. Corrales-Medina VF, Musher DM, Wells GA, Chirinos JA, Chen, Fine MJ. Cardiac complications in patients with community-acquired pneumonia: incidence, timing, risk factors, and association with short-term mortality. Circulation 2012; 125:773-81.

8. Cornett E, Novitch MB, Kaye AD, Pann CA, Bangalore HS, Allred $G$, et al. Macrolide and fluoroquinolone mediated cardiac arrhythmias: clinical considerations and comprehensive review. Postgrad Med 2017;129(7):715-24.

9. Roed T, Schonheyder $\mathrm{HC}$, Nielsen $H$. Predictors of positive or negative legionella urinary antigen test in community- $a$ cquired pneumonia. Infec Dis (London) 2015;47:484-90.

10. Valencia $M$, Badia JR, Cavalcanti M, Ferrer M, Agustí C, Angrill J, García E, Mensa J, Niederman MS, Torres A. Pneumonia severity index class $v$ patients with community- $a$ cquired pneumonia: characteristics, outcomes, and value of severity scores. Chest 2007;132(2):515-22.

11. Oliveira B, Nora D, Carvalho T, Araujo AM, Valente L, Gomes $P$, et al. 2014's legionnaires' disease outbreak in Portugal-an intensive care, single-center. 29 patient case series. Intensive Care Med Exp 2015;3(Suppl 1):A353. 
12. Erdogan H, Erdogan A, Lakamdayali H, Yilmaz A, Arslan $H$. Travel-associated Legionnaires' disease: clinical features of 17 cases and a review of the literature. Diagn Microbiol Infect Dis 2013;68(3):297-303.

13. Corrales-Medina VF, Musher DM, Shachkina S, Chirinos JA. Acute pneumonia and the cardiovascular system. Lancet 2013;381(9865):496-505.

14. Cangemi R, Calvieri C, Falcone M, BucciT, Bertazzoni G Relation of cardiac complications in the early phase of community-acquired pneumonia to long-term mortality and cardiovascular events. Am J Card 2015;116:647-51.

15. Kwong JC, Schwartz KL, Campitelli MA, Chung H, Crowcroft NS, Campitelli MPH, et al. Acute myocardial infarction after laboratory-confirmed influenza infection. N Engl J Med 2018;378:345-53.

16. Ishimaru N, Suzuki H, Tokuda Y, Takano T. Severe Legionnaires' disease with pneumonia and biopsy-confirmed myocarditis most likely caused by Legionella pneumophila serogroup 6. Intern Med 2012;51:3207-12.

17. Burke PT, Shah R, Thabolingam R, Saba S. Suspected Legionella-induced perimyocarditis in an adult in the absence of pneumonia: A rare clinical entity. Eur I Intern Med 2019;62:e13-e14.

18. Coimbra JF, Carreira MS, Cunha AL, Rebelo S, Pereira JM. Cardiovascular events and de novo AF following Legionnaires' disease. Eur J Intern Med 2019;62:e13-e14.

19. Zhu J, Zhang X, Shi G, Yi K, Tan X. Atrial fibrillation is an independent risk factor for hospital-acquired pneumonia. PLoS One 2015;10:e0131782.
20. Moammar MQ, Ali MI, Mahmood NA, DeBari VA, Khan MA. Cardiac troponin I levels and alveolar-arterial oxygen gradient in patients with community-acquired pneumonia. Heart Lung Circ 2010;19(2):90-2.

21. Erdogan H, Eldem HO. A Patient with Suspected Myocarditis Associated with Legionnaires' Disease: A Case Report and Review of the Literature. Mediterr I Infect Microb Antimicrob 2017;6.10.4274/mjima.2017.2.

22. Liu X, Ma J, Huang L, Zhu W, Yuan P, Wa R, et al. Fluoroquinolones increase the risk of serious arrhythmias: $A$ systematic review and meta-analysis. Medicine (Baltimore) 2017;96:e8273.

23. Li X, Wang M, Liu G. Macrolides use and the risk of sudden cardiac death. Expert Rev Anti Infect Ther 2016;14:535-7.

24. Zhou SF. Drugs behave as substrates, inhibitors and inducers of human cytochrome P450 3A4. Curr Drug Metab 2008;9(4):310-22.

\section{Address for Correspondence/Yazıșma Adresi}

\section{Dr. Sinan AKINCI}

Bașkent Üniversitesi Tip Fakültesi,

Alanya Uygulama ve Araștırma Merkezi,

Kardiyoloji Anabilim Dalı

Ankara-Türkiye

E-posta: akincisinan@gmail.com 